J. Asiat. Soc. Bangladesh, Sci. 46(1): 71-80, June 2020

\title{
GROWTH AND DEVELOPMENT OF NESTLINGS OF WHITE-THROATED KINGFISHER, HALCYON SMYRNENSIS (LINNAEUS, 1758)
}

\author{
HABIBON NAHER ${ }^{* 1}$ AND NOOR JAHAN SARKER ${ }^{2}$ \\ ${ }^{I}$ Department of Zoology, Jagannath University, Dhaka-1100, Bangladesh \\ ${ }^{2}$ Department of Zoology, University of Dhaka, Dhaka-1000, Bangladesh
}

\begin{abstract}
The growth and development of the nestlings of white-throated kingfisher (Halcyon smyrnensis) showed that at the hatching day, the mean body weight was $14.6 \pm 1.0 \mathrm{~g}$ which gained up to $69.9 \pm 3.0 \mathrm{~g}$ during fledging. The mean length of the body, wing, beak, head, tarsus and feet were $59.4 \pm 12.4,19.4 \pm 5.7,3.1 \pm 1.2,11.7 \pm 1.4,8.5 \pm 1.8$ and $17.3 \pm 3.6$ $\mathrm{mm}$, respectively at the hatching day and $203.5 \pm 14.1,105.7 \pm 5.8,40.4 \pm 1.3,29.1 \pm 1.1$, $14.9 \pm 0.4$ and $29.8 \pm 0.7 \mathrm{~mm}$, respectively during fledging day. The primaries, rectrices and the claw was started to grow from $3^{\text {rd }}$ day hatching and grew up to $67.8 \pm 5.6$, $27.7 \pm 3.4$ and $5.2 \pm 0.2 \mathrm{~mm}$, respectively during fledging time.
\end{abstract}

Key words: Nestlings, White-throated, Kingfisher, Development, Hatching, Fledging day

\section{Introduction}

White-breasted or white-throated kingfisher (Halcyon smyrnensis) is a very common resident bird of various habitats, mostly in the plains of open country with trees, electric wires and other perches (Ali et al. 2010). It ranges throughout much of the Indian subcontinent, except parts of the north-west (Grimmett et al. 1998). It nests in holes in sandy or loamy embankments which are considered as providing protection from changes in weather (Hoogland and Sherman 1976) and from predators (Lack 1968). But the Kingfisher's mortality increases as a result of human anthropogenic activities (Animal Diversity 2019). Water pollution, bioaccumulation of pollution and toxins in fishes affect the mortality rates of kingfishers or changes in water habitat reduce the number of nesting sites for kingfishers. Nestlings also die from flooding of the nest (Animal Diversity 2019). Kingfishers have relatively high reproductive rates, compensating for increased mortality in some areas (Fioratti 1992, Rayner et al. 1991).

In addition to some casual information on status and distribution of kingfishers in Bangladesh (Islam and Kamruzzaman 2008, Reza et al. 2003, Islam et al. 1999, Husain 1979, Khan 1986), some information are available on food habits, preying frequency, preying techniques, nesting behaviour (Naher and Sarker 2014, 2015, 2016, 2018). Some

*Corresponding author: likhi.habibon@gmail.com 
information are available on the growth of white-throated kingfisher in Cauvery Delta of Tamil Nadu in Southern India (Ali et al. 2010). Information on growth and development of nestlings of kingfishers in Bangladesh is scanty. Therefore, an attempt has been taken to study the growth and development of the nestlings of white-throated kingfisher during their nestling periods. The main objective of this study was to establish the weight of the body and length of different body parts of the nestlings of white-throated kingfisher during nesting period.

\section{Materials and Methods}

The study was carried out from September, 2008 to August, 2011. Growth changes in the nestlings were measured from hatching to fledging day. All the nests were visited at every third day, taking both photographs of the young and morphometric measurements of body parts. In total, 167 observations were taken. Altogether, 27 nestlings were examined, 20 from Dhaka district and seven from Chittagong University Campus (CUC). A total of 17 nestlings (12 from Dhaka and 5 from CUC) were able to fly due to loss of nestlings for various reasons. Disturbances were minimized by handling the nestlings very carefully during taking the measurements. All the nestlings were allotted individual identification marks with permanent ink pen. The measurements of different parameters were taken followed by Ali et al. (2010): (i) body weight, using a spring balance (graduated between 5 and $1000 \mathrm{~g}$ ) and pan balance (graduated between 0 and $2000 \mathrm{~g}$ ), (ii) body length, from the tip of the beak to the tip of the longest rectrix, using a slide calipers (graduated up to 0 to $150 \mathrm{~mm}$ ) and steel scale $(0$ to $300 \mathrm{~mm}$ ), (iii) wing length, as the straight length from the bend of the wing to the tip of the wing, using a tape scale, (iv) length of the primaries, from the tip of the wing to the tip of the longest primary, using a tape scale, (v) tail feather or rectrices length, the distance from the tip of the longest rectrix to the base of the middle rectrices, using a tape scale, (vi) tarsus length, measurement from the base of the tarso-metatarsus to the base of the middle toe, using a slide calipers, (vii) head length, from the culmen to the nape, using slide calipers, (viii) bill/beak length, from the tip of the mandible to the base of the culmen, (ix) claw length, from the base to the tip of the claw, using a slide calipers and (x) feet length, from the middle toe to the posterior toe or hallux, using a slide calipers.

Study area: The study was carried out at Dhaka and Chattagram. In Dhaka, the nests in Madhabchala and Boro-Walia villages of Savar Upazila and in Chattagram, Chittagong University Campus (CUC), Bangladesh were selected for collecting data on growth of the nestlings. 
The Madhabchala of Savar Upazila in Dhaka district is located at the western side of Jahangirnagar University of Savar. The Barawala was located at the western side of the village Madhabchala. The vegetation of the study sites was several fruiting (mango, Mangifera indica; jackfruit, Artocarpus heterophyllus; jam, Syzygium cumini; coconut, Cocos nucifera; jambura, Citrus grandis; guava, Psidium guajava) and wood trees (koroi, Albizia procera; segun, Tectona grandis) and bamboo (Bambusa sp.)

The CUC is located at the village Fatehpur under Hathazari Upazila of Chattagong district. The CUC stretches over 512.2 ha landscape of green hills, undulating valleys, moulds, plain grassland, bush and forests (Islam et al. 1979). Seventy-two per cent of the campus area is hilly and comprising small hills and the remaining areas are either plains or valleys (Islam et al. 1979). There are some creeks and streams within the hill area. Vegetation type is mixed-evergreen (Champion 1936). The natural vegetation of the campus is affected by biotic and abiotic factors especially due to human habitations and earth erosions. Consequently the primary vegetation of this area is totally lost. Hence, the vegetation of this area is now secondary one. The secondary forest grew with weeds environment such as thickest with a few scattered trees, thatching grasses and some bamboos (Chowdhury 2002).

\section{Results and Discussion}

The measurements of the growth and development of different body parts of the nestlings of the white-throated kingfisher are described under the following headings.

Body weight (in g): At hatching day, the average weight of the nestlings was $14.6 \pm 1.0 \mathrm{~g}$ (range 12.0-16.46, $\mathrm{n}=27$ ). The nestling gained weight gradually and reached maximum of 70.8 $\pm 4.6 \mathrm{~g}$ at 15 days (range 63.1-79.9, $\mathrm{n}=27$ ) from the first hatching. The weight $(63.5 \pm 5.9 \mathrm{~g}$, range 54.9-75.9 $\mathrm{g}, \mathrm{n}=17)$ then started to decline (13.2\%). After 18 days, the nestling gained weight again $(69.9 \pm 3 \mathrm{~g}$, range $63.3-73.9 \mathrm{~g}, \mathrm{n}=17)$ up to fledging time $\left(21^{\text {st }}\right.$ days) (Fig. 1). Ali et al. (2010) reported that nestlings of the white-throated kingfisher grew from 3.7 to peak weight of $70.5 \mathrm{~g}$, then slowly declined and reached to the weight of $61.8 \mathrm{~g}$ at the time of fledging. Many observers have noted a decrease in rate-of-gain in weight (Naher and Sarker 2011, Welty 1982) as feathers were being produced or as temperature control was being established (Ali et al. 2010) or due to the utilization of fat deposits and skeletal muscles for the energy to leave the nest (Welty 1982). This body weight reduction at fledging day is advantageous for moving out from the nest (Kumar and Rao 1984, Haggerty 1994, McCarty 2001, Penteriani et al. 2005, Greeny 2008, Asokan et al. 2009a,b, Asokan et al. 2010). 
The average growth rate of the nestling of the white-throated kingfisher was $2.6 \mathrm{~g}$ per day during nesting period. The weight of the nestlings found significantly increasing $\left(\chi^{2}=\right.$ $84.5, \mathrm{df}=7, \mathrm{p}<0.001)$ and the increasing trend was significantly correlated with the age of the nestlings $(r=0.963, \mathrm{df}=7, \mathrm{p}<0.001)$.

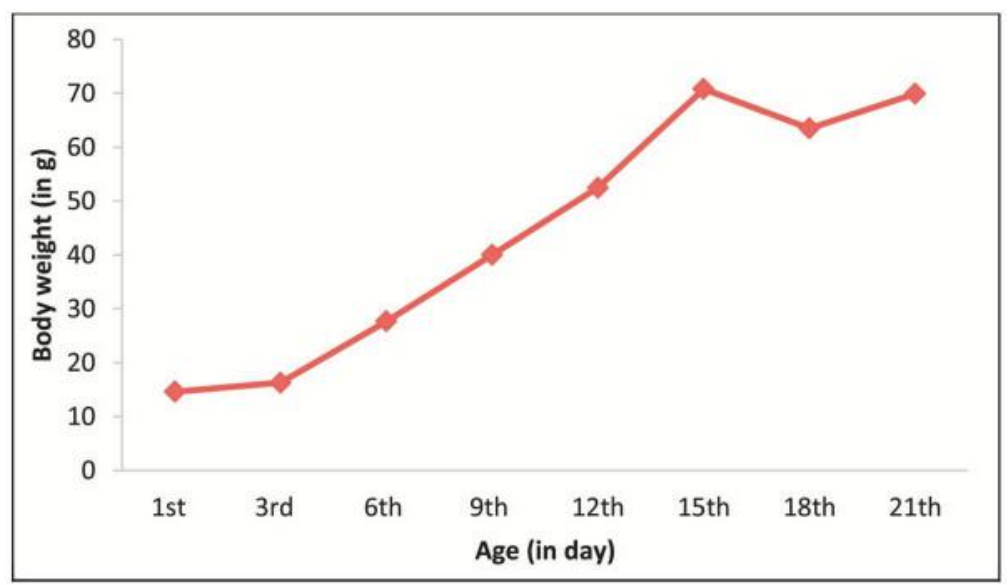

Fig. 1. Growth of the body weight (g) of white-throated kingfisher.

Body length $(\mathrm{mm})$ : The average body length of the nestlings was $59.4 \pm 12.4 \mathrm{~mm}$ (range $50-68.2 \mathrm{~mm}, \mathrm{n}=27$ ) at hatching day and $203.5 \pm 14.1 \mathrm{~mm}$ (range $182-230 \mathrm{~mm}, \mathrm{n}=17$ ) at the fledging day. Thus the average body length increased per day was $6.8 \mathrm{~mm}$. The growth rate increased rather steadily from 3 to $6^{\text {th }}$ day (Fig. 2). The body length of nestlings reached from $3.7 \pm 0.21 \mathrm{~cm}$ at hatching to $21.9 \pm 0.16 \mathrm{~cm}$ by the end of day 27 at Tamil Nadu in India (Ali et al. 2010) which is very close to present study.

The length of total body of the nestlings was found significantly increasing $\left(\chi^{2}=84.5\right.$, $\mathrm{df}=7, \mathrm{p}<0.001)$ and the increasing trend was significantly correlated with the age of the nestlings $(\mathrm{r}=0.992, \mathrm{df}=7, \mathrm{p}<0.001)$.

Wing length $(\mathrm{mm})$ : At hatching day, the average wing length of the nestlings was $19.4 \pm$ $5.7 \mathrm{~mm}$ (range 14-26.02 $\mathrm{mm}, \mathrm{n}=27$ ). It was increasing up to $105.7 \pm 5.8 \mathrm{~mm}$ (range 94$110 \mathrm{~mm}, \mathrm{n}=17$ ) during fledging day. Thus the average wing length increased per day was $4.1 \mathrm{~mm}$. The growth rate increased rather sharply during $6-9^{\text {th }}$ day.

The length of wing of the nestlings was found significantly increasing $\left(\chi^{2}=93.2, \mathrm{df}=7\right.$, $\mathrm{p}<0.001)$ and the increasing trend was significantly correlated with the age of the nestlings $(\mathrm{r}=0.992, \mathrm{df}=7, \mathrm{p}<0.001)$. 
Head length (in mm): The average head length of the nestlings' was $11.7 \pm 1.4 \mathrm{~mm}$ (range 8.1-18 mm, n=27) at hatching day and 29.1 $\pm 1.1 \mathrm{~mm}$ (range 28-31 mm, n=17) at fledging day. Thus the average head length increased was $0.8 \mathrm{~mm}$ per day.

The length of head of the nestlings was found significantly increasing $\left(\chi^{2}=14.9, \mathrm{df}=7\right.$, $\mathrm{p}<0.05)$ and the increasing trend was significantly correlated with the age of the nestlings $(\mathrm{r}=0.978, \mathrm{df}=7, \mathrm{p}<0.001)$.

Beak length (in $\mathrm{mm}$ ): The average beak length of the nestlings' was $3.1 \pm 1.2 \mathrm{~mm}$ (range 2.1-5.12 mm, $\mathrm{n}=27$ ) at hatching day and 40.4 $\pm 1.3 \mathrm{~mm}$ (range 36.7-42.5 mm, $\mathrm{n}=17$ ) at fledging day. Thus the average growth rate of beak was $1.8 \mathrm{~mm}$ per day. The bill length was $0.6 \pm 0.14 \mathrm{~cm}$ at hatching and it reached $4.5 \pm 0.05 \mathrm{~cm}$ on day 27 which is almost the same to the finding of Ali et al. (2010) at Tamil Nadu in India.

The length of beak of the nestlings was found significantly increasing $\left(\chi^{2}=47.8, \mathrm{df}=7\right.$, $\mathrm{p}<0.001)$ and the increasing trend was significantly correlated with the age of the nestlings $(\mathrm{r}=0.973, \mathrm{df}=7, \mathrm{p}<0.001)$.

Length of primaries $(\mathrm{mm})$ : During hatching, the hatchling was naked, there was no feather over the body. From the $4^{\text {th }}$ day of hatching, the primary feather of the wing started to grow slowly and it was increased up to $67.8 \pm 5.6 \mathrm{~mm}$ (range 57.1-74.2 $\mathrm{mm}$, $\mathrm{n}=17$ ) during fledging (Fig. 2). Thus, the average growth rate of primaries was $3.8 \mathrm{~mm}$ per day. The growth was highly occurred from 15 to 18 days. In Tamil Nadu in India the length of wing of white-throated kingfisher was $1.4 \pm 0.09 \mathrm{~cm}$ at the time of hatching, and it gradually increased and attained maximum length of $16.4 \pm 0.10 \mathrm{~cm}$ on day 27 (Ali et al. 2010). Cramp et al. (1988) reported that the feathers of pied kingfisher started to grow by the $4^{\text {th }}$ day and flight feathers by the 11 to $13^{\text {th }}$ days and fully developed in six weeks after leaving the nest.

The length of the primaries of the nestlings was found significantly increasing $\left(\chi^{2}=94.9\right.$, $\mathrm{df}=5, \mathrm{p}<0.001)$ and the increasing trend was significantly correlated with the age of the nestlings $(\mathrm{r}=0.987, \mathrm{df}=5, \mathrm{p}<0.001)$.

Length of tail feather or rectrices $(\mathrm{mm})$ : It is mentioned earlier that the hatchlings were naked during hatching. Rectrices started growing after the $7^{\text {th }}$ day of hatching. During fledging it reached upto $27.7 \pm 3.4 \mathrm{~mm}$ (range 19.1-32.1 mm, n=17) (Fig. 2). Thus, the average growth rate of rectrices was $1.2 \mathrm{~mm}$. In Tamil Nadu, India the length of the tail of white-throated kingfisher was $0.2 \pm 0.05 \mathrm{~cm}$ at hatching and it increased to $4.3 \pm 0.04 \mathrm{~cm}$ during day 27 (Ali et al. 2010). 
The length of the tail feather (rectrices) of nestlings was found significantly increasing $\left(\chi^{2}=32, \mathrm{df}=4, \mathrm{p}<0.001\right)$ and the increasing trend was significantly correlated with the age of the nestlings $(\mathrm{r}=0.981, \mathrm{df}=4, \mathrm{p}<0.001)$.

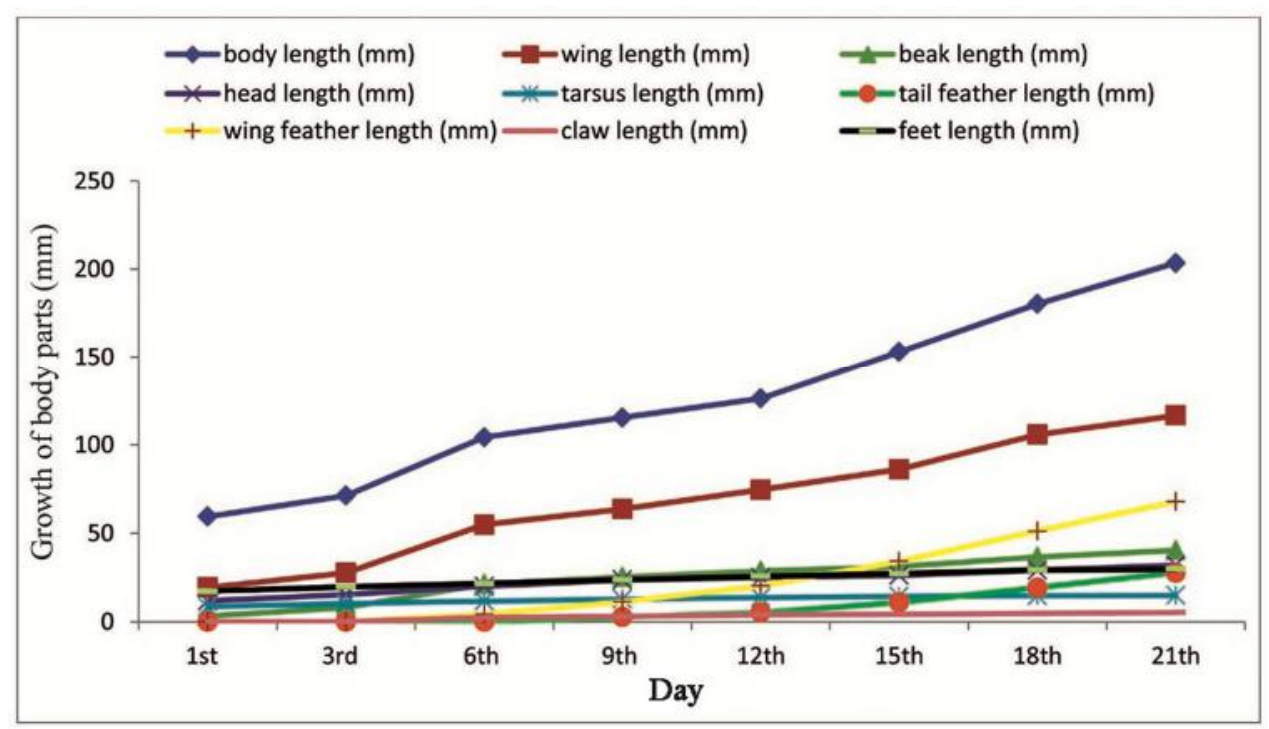

Fig. 2. Growth of different body parts $(\mathrm{mm})$ of white-throated kingfisher.

Tarsus length (in $\mathrm{mm}$ ): The average tarsus length of the nestlings' was $8.5 \pm 1.8 \mathrm{~mm}$ (range 8-9.9 mm, $\mathrm{n}=27$ ) at hatching day and 14.9 $\pm 0.4 \mathrm{~mm}$ (range 14.4-15.8 mm, $\mathrm{n}=17$ ) at fledging day (Fig. 2). Thus, the average tarsus length increased was $0.3 \mathrm{~mm}$ per day. The tarsus length during hatching was $0.6 \pm 0.14 \mathrm{~cm}$ and attained the maximum size of $3.5 \pm 0.04 \mathrm{~cm}$ during fledging at Tamil Nadu in India (Ali et al. 2010).

The length of the tarsus of the nestlings was found significantly increasing $\left(\chi^{2}=2.9, \mathrm{df}=7\right.$, $\mathrm{p}>0.05$ ) and the increasing trend was significantly correlated with the age of the nestlings $(\mathrm{r}=0.964, \mathrm{df}=7, \mathrm{p}<0.001)$.

Claw length (in $\mathrm{mm}$ ): There was no sign of claw of the nestlings at hatching day to the $3^{\text {rd }}$ day of their life. The average claw length of the nestlings at fledging day was $5.2 \pm 0.2$ $\mathrm{mm}$ (range 4.6-5.6 mm, $\mathrm{n}=17$ ). Thus the average growth rate of claw was $0.2 \mathrm{~mm}$ per day.

The length of claw of the nestlings was found significantly increasing $\left(\chi^{2}=1.4, \mathrm{df}=5\right.$, $\mathrm{p}>0.05)$ and the increasing trend was significantly correlated with the age of the nestlings $(\mathrm{r}=0.989, \mathrm{df}=5, \mathrm{p}<0.001)$. 

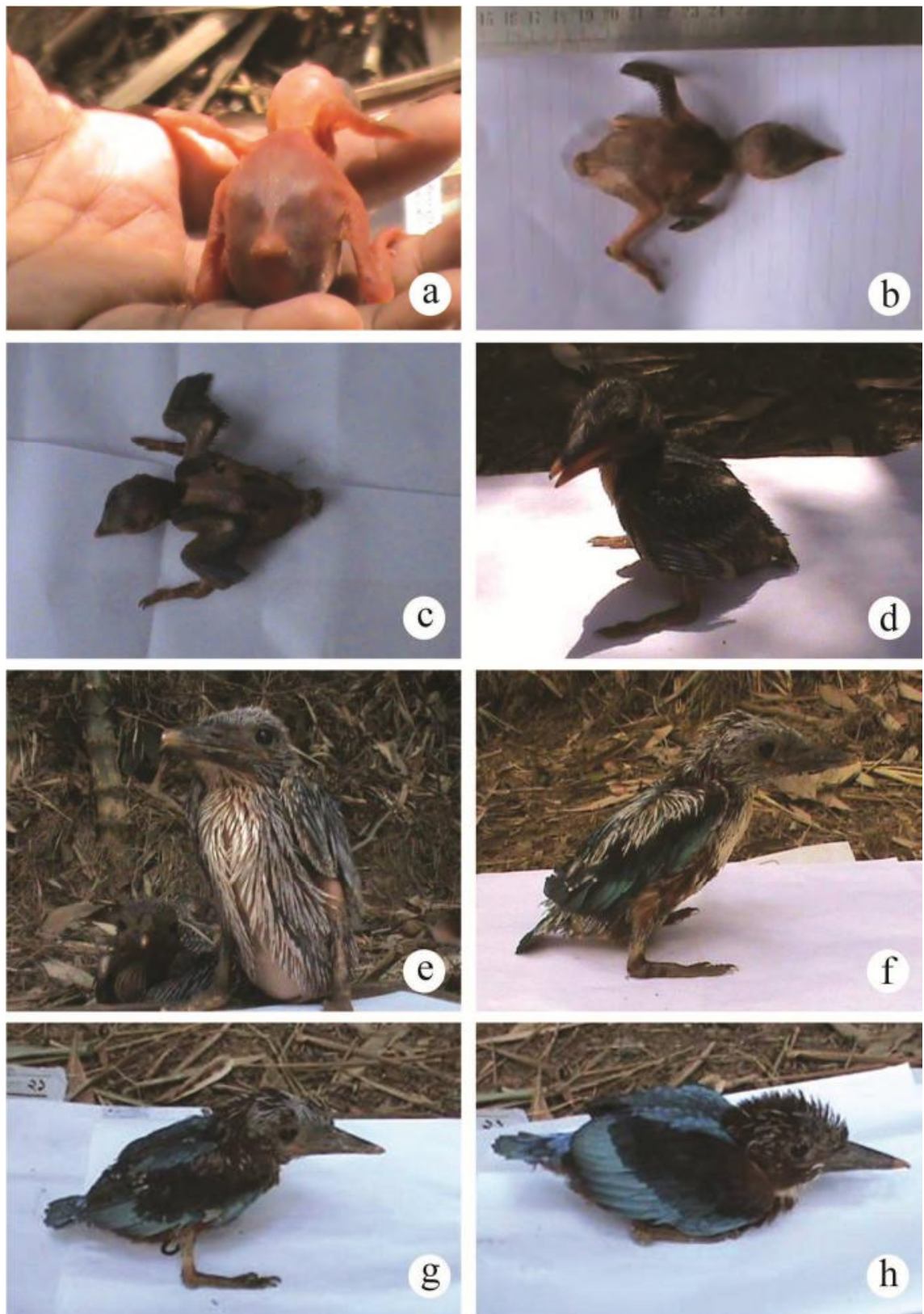

Fig. 3. Nestlings of white-throated kingfisher at different ages from hatching day to fledging day, (a) New born hatchling, (b) 3 days old, (c) 6 days old, (d) 9 days old, (e) 12 days old, (f) 15 days old, (g) 18 days old, and (h) 21 days old. 
Feet length $(\mathrm{mm})$ : The average feet length of the nestlings was $17.3 \pm 3.6 \mathrm{~mm}$ (range 16.3$19.8 \mathrm{~mm}, \mathrm{n}=27$ ) at hatching day and $29.8 \pm 0.7 \mathrm{~mm}$ (range 29.1-30.7 mm, $\mathrm{n}=17$ ) at fledging day. Thus the average growth rate was $3.03 \mathrm{~mm}$ per day.

The length of feet of the nestlings was found significantly increasing $\left(\chi^{2}=5.84, \mathrm{df}=7\right.$, $\mathrm{p}>0.05)$ and the increasing trend was significantly correlated with the age of the nestlings $(\mathrm{r}=0.994, \mathrm{df}=7, \mathrm{p}<0.001)$.

The growth and development of different body parts was gradually increasing from the hatching day to fledging day (Fig. 3). The length of all body parts attained the maximum maturity at the time of fledging stage (Fig. 2). The present observations support the views of Ali et al. (2010), Naher and Sarker (2011). The white-throated kingfisher used different body parts immediately after fledging for successful survival. This kind of growth in the adaptive parts was observed in several avian species by many workers (Zach and Mayoh 1982, Kumar 1983, Teather 1996, Aparicio 2001, Pereyra and Morton 2001, Asokan et al. 2009a,b, 2010).

During hatching, the hatchling was naked with pinkish colour. It could not stand and there was no primaries, rectrices and claws. It could stand at the $9^{\text {th }}$ days of its age. During $21^{\text {st }}$ days, it could glide from nest to nearest branch of the tree. Within 24 to 26 days after hatching, the total clutch would able to leave the nest.

\section{Acknowledgements}

The authors are grateful to the Ministry of Science, Information and Communication Technology for funding the research. They express their heartiest gratitude to the villagers who helped them during data collection.

\section{References}

Ali, A.M.S., S. Asokan, and R. Manikannan. 2010. Observations on nesting ecology of whitebreasted kingfisher Halcyon smyrnensis (Aves: Coraciiformes) in Cauvery Delta, Tamil Nadu, Southern India. J. Ecol. Natur. Environ. 2(7): 134-139.

Animal Diversity. 2019. Available at http://animaldiversity.ummz.umich.edu/site/accounts/ information/ Halcyon_smyrnensis.html. Accessed date 21-05-2019.

Aparicio, J.M. 2001. Patterns of growth and fluctuating asymmetry: The effects of asymmetrical investment in traits with determinate growth. Behav. Ecol. Sociobiol. 49: 273-282.

Asokan, S., A.M.S. Ali and R. Manikannan. 2009a. Nest-site selection and nestling growth patterns of the Common Myna, Acridotheres tristis (Linnaeus, 1766). Geobios 36: 65-70.

Asokan, S., A.M.S. Ali, and R. Manikannan. 2009b. Preliminary investigations on diet and breeding biology of the Indian Roller Coracias benghalensis in a Portion of Cauvery Delta, Tamil Nadu, India. World J. Zool. 4(4): 263-269. 
Asokan, S., A.M.S. Ali and R. Manikannan. 2010. Breeding biology of the Small Bee-eater Merops orientalis (Latham, 1801) in Nagapattinam District, Tamil Nadu, India. J. Threat. Taxa. 2(4): 797-804.

Champion, HG.1936. A preliminary survey of the forest types of India and Burma Indian Forest Records (new series). Silviculture 1(1):365.

Chowdhury, M.S.H. 2002. Forest management plan for the working plan estate of Chittagong University 2002-2003 to 2012-2013. Unpublished project paper. University of Chittagong. pp. 148.

Cramp, S., Douthwaite, R., Reyer, K., Westerturp. 1988. Ceryle rudis (Linnaeus). Pied Kingfisher. In: H. Fry, S. Keith, E. Urban, eds. The Birds of Africa. Vol. III, San Diego: Academic Press. pp. 299-302.

Fioratti, P. 1992. Kingfisher. Harper Collins Publishers. London.

Greeny, H.F. 2008. Nestling growth and plumage development of the spotted Barb tail (Premnoplex brunnescens). Kempffiana 4: 21-29.

Grimmett, R., C. Inskipp, and T. Inskipp. 1998. Birds of the Indian Subcontinent. Oxford University Press, New Delhi. pp. 1-888.

Haggerty, T.M. 1994. Nestling growth and development in Bachman's Sparrows. J. Field Ornithol. 65: $224-231$.

Hoogland, J.L. and Sherman, P.W. 1976. Advantages and disadvantages of Bank Swallow (Riparia riparia) coloniality. Ecol. Monogr. 46: 33-58.

Husain, K.Z. 1979. Birds of Bangladesh. Eden press, Dhaka, Bangladesh. pp. 1-84.

Islam, A.T.M., Chowdhury, M.S., Haque, A.K.M.M. and Malek, S.A. 1979. Detailed soil survey in Chittagong University Campus. Department of soil survey, Chittagong. pp. 207.

Islam,M.A., M.M.H., Khan, M.M. Kabir, T. Solhoy, N.B. Jordar and M.M. Feeroz. 1999. Winter birds of the Sundarbans, Bangladesh. Ecoprint. 6(1): 41-49.

Islam, M. A. and Kamruzzaman, M. 2008. Halcyon smyrnensis. In: Siddiqui, K.U., M.A. Islam, S.M.H. Kabir, M. Ahmad, A.T.A. Ahmed, A.K.M. Rahman, , E.U. Haque, , Z.U. Ahmed, , Z.N.T. Begum, M.A. Hassan, M. Khondker and M.M. Rahman (eds.). Encyclopedia of Flora and Fauna of Bangladesh. Vol. 26. Birds. Asiatic Society of Bangladesh, Dhaka. pp. 69-70.

Khan, M.A.R. 1986. Wildlife in Bangladesh mangrove ecosystem. J. Bombay Nat. Hist. Soc. 83: 32-40.

Kumar, T.S. 1983. Bill growth in the spotted Owlet Athene brama brama (T). Raptor Res. Cent. Publ. 2: 1-4.

Kumar, T.S. and J.V.R. RAO. 1984. Some observation on the weights of nestling Spotted Owlet Athene brama brama (T) prior to flying. Geobios 11: 229-231.

Lack, D. 1968: Ecological adaptations for breeding in birds. Methuen, London, pp. 409.

McCarty, J.P. 2001. Variation in growth of nestling Tree Swallows across multiple temporal and spatial scales. Auk. 118: 176-190.

Naher, H. and N. J. Sarker. 2011. Growth and development pattern of the Little Cormorant (Phalacrocoraxniger) in Bangladesh. Bangladesh J. Zool. 39(1): 69-76.

Naher, H. and N. J. Sarker. 2014. Food and feeding habits of White-throated Kingfisher (Halcyon smyrnensis) in Bangladesh. Bangladesh J. Zool. 42(2): 237-249.

Naher, H. and N. J. Sarker. 2015. Prey capturing techniques of White-throated Kingfisher (Halcyon smyrnensis) in Dhaka, Bangladesh. Jagannath Univ. J. Life and Earth Sci. 1(1): 95-102.

Naher, H. and Sarker, N. J. 2016. Nest and nest characteristics of Common (Alcedo atthis) and White-throated Kingfisher (Halcyon smyrnensis). Bangladesh J. Zool. 44(1): 99-110.

Naher, H. and Sarker, N. J. 2018. Provisioned food to the nestlings of common kingfisher (Alcedo atthis) and white-throated kingfisher (Halcyon smyrnensis) by their parents. Jagannath Univ. J. Life Earth Sci. 4(2): 176-186. 
Penteriani, V., M.M. Delgado, C. Maggio, A. Aradis and F. Sergio. 2005. Development of chicks and pre-dispersal behaviour of young in the Eagle Owl (Bubo bubo). Ibis. 147: 155-168.

Pereyra, M.E. and M.L. Morton. 2001. Nestling growth and thermoregulatory development in subalpine Dusky Flycatchers. Auk. 118: 116-136.

Rayner, J., Norberg, U. and Brooke, M. 1991. Movement, A survey of modern birds. In: Brooke, M., Birkhead, T. eds. The Cambridge Encyclopedia of Ornithology. $1^{\text {st }}$ edition. The press syndicate of the University of Cambridge, New York. pp. 62.

Reza, A.H.M.A., M.M. Feeroz, M.A. Islam and M.M Kabir. 2003. Status and density of Kingfishers (family: Alcedinidae, Halcyonidae and Cerylidae) in the Sunderbans mangroves forest, Bangladesh. Bangladesh J. Life Sci. 15(1): 55-60.

Teather, K. 1996. Patterns of growth and asymmetry in nestling Tree Swallows. J. Avian Biol. 27: 302-310.

Welty, C. J. 1982. The life of birds. W.B. Saunders Company, London. xiii + pp. 545.

Zach, R. and K. R. Mayoh. 1982. Weight and feather growth of nestling Tree Swallows. Cana. J. Zool. 60: 1080-1090.

(Revised copy received on 24.03.2020) 